\title{
Knowledge, Attitudes and Practices towards Medical Ethics among Specialist Medical Officers of Selected Allopathic Healthcare Institutions in Sri Lanka
}

\section{Conocimiento, actitudes y prácticas hacia la ética médica entre los funcionarios médicos especialistas de instituciones sanitarias alopáticas seleccionadas en Sri Lanka}

DOI: $10.46981 / \mathrm{sfjhv2n3-002}$

Received in: April 1st, 2021

Accepted in: May 31th, 2021

\section{P Jayalath}

Master of Sciences (Medical Administration) from Post Graduate Institute of Medicine University of Colombo

Institution: Ministry of Health, Nutrition \& Indigenous Medicine

Address: No 117/D, Koskolawattha, Pitumpe, Padukka, Sri Lanka

E mail: priyanwadaj@gmail.com

\section{R Nanayakkara}

Master of Sciences (Medical Administration) from Post Graduate Institute of Medicine University of Colombo

Institution: Ministry of Health, Nutrition \& Indigenous Medicine Address: 542/22 Central Avenue, Welegoda, Matara, Sri Lanka

E mail: rameshnanayakkara@yahoo.com

\section{K M P D Jayasundara}

Master of Sciences (Medical Administration) from Post Graduate Institute of Medicine University of Colombo

Institution: Ministry of Health, Nutrition \& Indigenous Medicine

Address: No.28, Darshanapura, Kundasale, Sri Lanka

E mail: dinukapj@yahoo.com

\section{M Abeysekara}

Master of Sciences (Medical Administration) from Post Graduate Institute of Medicine University of Colombo

Institution: Ministry of Health, Nutrition \& Indigenous Medicine

Address: 308/68C, Middle Road, Welegoda, Matara, Sri Lanka

E mail: Chandanaabeysekara1@gmail.com

A M J Abeynayake

Master of Sciences (Medical Administration) from Post Graduate Institute of Medicine University of Colombo

Institution: Ministry of Health, Nutrition \& Indigenous Medicine

Address: 14 B,Reymond Road, Nugegoda, Sri Lanka

E mail: anujay82@gmail.com

\section{ABSTRACT}

Ethics is the "study of morality - careful and systematic analysis of moral decisions and behaviors and practicing those decisions". The four ethical principles form the basis of ethical medical practice, 
namely, autonomy, justice, beneficence, and non-maleficence. A descriptive cross-sectional study was done among 120 specialist medical officers in four selected allopathic healthcare institutions in Sri Lanka, using a pretested validated self-administered questionnaire in 2021 to describe their knowledge, attitudes and practices related to medical ethics. The response rate was $90.00 \%(n=108)$. When considering the knowledge and attitudes related to medical ethics it was found that the majority $(n=64,59.30 \%)$ of the specialist medical officers strongly disagree that "confidentiality is not so important aspect of treatment". Among the total respondents 26(24.10\%) strongly agree and 54 respondents (50\%) agree with statement "close relatives should be told about patients condition". When considering the practices related to medical ethics, we found that "if a patient wishes to die, he or she should be assisted in doing so no matter what their illness" is the ethical practice to which $32(29.60 \%)$ respondents strongly disagree with and 56(51.90\%) disagree with. We further discovered that $48(44.40 \%)$ of the respondents strongly agree and $52(48.10 \%)$ agree with the practice "ethics as a part of syllabus should be taught in every medical teaching institution". These findings imply that Sri Lankan specialist doctors have a sound knowledge and positive attitudes towards the basic ethical principles. But they still need to improve their knowledge and attitudes related to ethical issues regarding their own colleagues. Continuous medical education for specialist medical officers, establishing ethics committees in hospitals, appointing ethicists to hospitals and conducting clinical case conferences regarding unethical practice are recommended to improve the situation.

Key words: medical ethics, knowledge, attitudes, practices

\section{RESUMEN}

La ética es el "estudio de la moralidad, es decir, el análisis cuidadoso y sistemático de las decisiones y comportamientos morales y la práctica de esas decisiones". Los cuatro principios éticos constituyen la base de la práctica médica ética, a saber, la autonomía, la justicia, la beneficencia y la no maleficencia. Se realizó un estudio transversal descriptivo entre 120 médicos especialistas de cuatro instituciones sanitarias alopáticas seleccionadas en Sri Lanka, utilizando un cuestionario autoadministrado validado previamente en 2021 para describir sus conocimientos, actitudes y prácticas relacionadas con la ética médica. La tasa de respuesta fue del 90,00\% ( $\mathrm{n}=108)$. Al considerar los conocimientos y las actitudes relacionados con la ética médica, se descubrió que la mayoría $(n=64,59,30 \%)$ de los médicos especialistas están muy en desacuerdo con que "la confidencialidad no es un aspecto tan importante del tratamiento". Del total de encuestados, 26 (24,10\%) están muy de acuerdo y 54 (50\%) están de acuerdo con la afirmación "se debe informar a los familiares cercanos sobre el estado del paciente". Al considerar las prácticas relacionadas con la ética médica, descubrimos que "si un paciente desea morir, se le debe ayudar a hacerlo sin importar su enfermedad" es la práctica ética con la que $32(29,60 \%)$ encuestados están muy en desacuerdo y 56 (51,90\%) están en desacuerdo. Además, descubrimos que $48(44,40 \%)$ de los encuestados están muy de acuerdo y $52(48,10 \%)$ están de acuerdo con la práctica "la ética como parte del programa de estudios debería enseñarse en todas las instituciones de enseñanza médica". Estos resultados implican que los médicos especialistas de Sri Lanka tienen un buen conocimiento y actitudes positivas hacia los principios éticos básicos. Sin embargo, todavía necesitan mejorar sus conocimientos y actitudes en relación con las cuestiones éticas de sus propios colegas. Para mejorar la situación, se recomienda la formación médica continua de los médicos especialistas, la creación de comités de ética en los hospitales, el nombramiento de especialistas en ética en los hospitales y la realización de conferencias sobre casos clínicos relacionados con prácticas no éticas.

Palabras clave: ética médica, conocimientos, actitudes, prácticas 


\section{INTRODUCTION}

Ethics is the study of morality - careful and systematic analysis of moral decisions and behaviors and practicing those decisions. Medical ethics is concerned with moral values and judgment as it applies to medicine (Iswarya \& Bhuvaneshwari, 2018). The four ethical principles form the basis of ethical medical practice, namely, autonomy, justice, beneficence, and non-maleficence (Beauchamp \& Childress JF, 2013). The origin of medical ethics in Western history can be traced back to early Christian teachings and Hippocratic Oath (Jatana et al., 2018).

Historically, there have been several reports emphasizing the significance of incorporating ethical issues into medical curricula (Jalal, Imran, Mashood, Younis, \& Peshawer, 2018). Hence, training in medical ethics has been made mandatory in the undergraduate curriculum by the regulatory bodies of medical education in many countries (Janakiram \& Gardens, 2014).

Despite numerous ethical codes and training in medical ethics, allegations against medical practitioners for violation of medical ethics is becoming increasingly common. Growing public awareness regarding the ethical conduct of healthcare practitioners and complaints against physicians appear to be escalating (Baldwin, Daugherty, \& Rowley, 1998). This may reflect an increase in unethical practices by healthcare providers or increasing public awareness of such unethical practices (Brogen, Rajkumari, Laishram, \& Joy, 2009).

Even specialist medical officers who should be role models for junior doctors cannot escape from allegations for violation of medical ethics. Therefore, the researchers decided to carry out this study to describe the knowledge, attitudes and practices related to medical ethics among specialist medical officers in selected allopathic healthcare institutions in Sri Lanka.

\section{METHODOLOGY}

This study was a descriptive cross-sectional study in which data collection was done for a period of 03 months from February 2021. The study was carried out in 04 health care institutions which were selected based on the convenience of the investigators but representing secondary and tertiary levels of healthcare, urban-rural environment in Sri Lanka as well as representing 04 provinces in the country. Total of 120 specialist medical officers which was the study population of all 04 healthcare institutions was recruited in the study. A self-administered questionnaire was used for data collection. It was developed based on questionnaire used by Chopra and others in 2011(Chopra et al., 2013). Face \& content validity was done with expert opinion. Pre-testing of the questionnaire was done at Base Hospital Karawanella. A 5-point Likert scale was used ranging from "Strongly Disagree "(1) to "Strongly Agree" (5) to assess the responses. Statistical analyses were completed using Microsoft Office Excel and Statistical Package for the Social Sciences (SPSS 21.0). Ethical approval was obtained from Ethical 
Review Committee Post Graduate Institute of Medicine Colombo. Administrative clearance was obtained from the relevant authorities.

\section{RESULTS}

The socio demographic characteristics of the participants are summarized in Table 1.

Table 1 Socio Demographic Characteristics of Participants

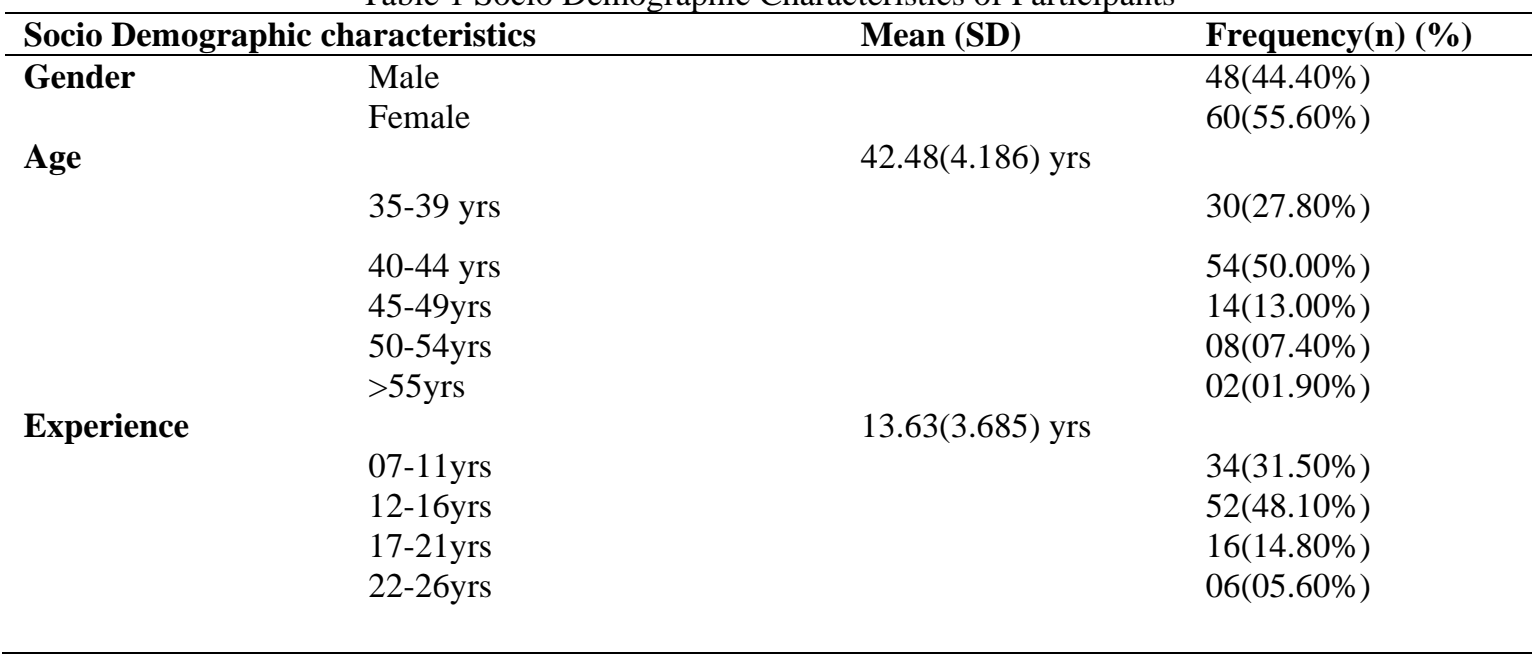

Out of the total number of participants $(\mathrm{N}=120)$, only 108 participants returned the completed questionnaire which resulted in a response rate of $90 \%$. Among the respondents, majority $(55.60 \%, \mathrm{n}=60)$ are females with a mean age of $42.48(\mathrm{SD}=4.186)$ years and mean experience of 13.63

$(\mathrm{SD}=3.685)$ years. The majority belong to the age group of $40-44$ years and experience group of $12-16$ years $(50.00 \%, \mathrm{n}=54)$ and $(48.10 \%, \mathrm{n}=52)$ respectively. (Table 1$)$.

Table 2 summarizes the respondents' knowledge and attitudes towards various dimensions of medical ethics in a 5-point Likert scale.

Table 2 Respondents' knowledge and attitudes towards various dimensions of medical ethics

\begin{tabular}{|c|c|c|c|c|c|}
\hline Issues in Medical Ethics & $\begin{array}{l}\text { Strongly } \\
\text { Disagree }\end{array}$ & Disagree & $\begin{array}{l}\text { Neither } \\
\text { Disagree or } \\
\text { Agree }\end{array}$ & Agree & $\begin{array}{l}\text { Strongly } \\
\text { Agree }\end{array}$ \\
\hline $\begin{array}{l}\text { 6. Patients wishes must always be adhered } \\
\text { to }\end{array}$ & $\begin{array}{r}00 \\
(00 \%)\end{array}$ & $\begin{array}{l}22 \\
(20.40 \%)\end{array}$ & $\begin{array}{l}28 \\
(25.90 \%)\end{array}$ & $\begin{array}{l}48 \\
(44.40 \%)\end{array}$ & $\begin{array}{l}10 \\
(9.30 \%)\end{array}$ \\
\hline $\begin{array}{l}\text { 7.Patients should be always informed if } \\
\text { health care professionals do something } \\
\text { wrong involving their treatment. }\end{array}$ & $\begin{array}{l}02 \\
(01.90 \%)\end{array}$ & $\begin{array}{l}20 \\
(18.50 \%)\end{array}$ & $\begin{array}{l}16 \\
(14.80 \%)\end{array}$ & $\begin{array}{l}54 \\
(50.00 \%)\end{array}$ & $\begin{array}{l}16 \\
(14.80 \%)\end{array}$ \\
\hline $\begin{array}{l}\text { 8. Confidentiality is not so important } \\
\text { aspect of treatment. }\end{array}$ & $\begin{array}{l}64 \\
(59.30 . \%)\end{array}$ & $\begin{array}{l}34 \\
(31.50 \%)\end{array}$ & $\begin{array}{l}02 \\
(01.90 \%)\end{array}$ & $\begin{array}{l}04 \\
(03.70 \%)\end{array}$ & $\begin{array}{l}04 \\
(03.70 \%)\end{array}$ \\
\hline
\end{tabular}




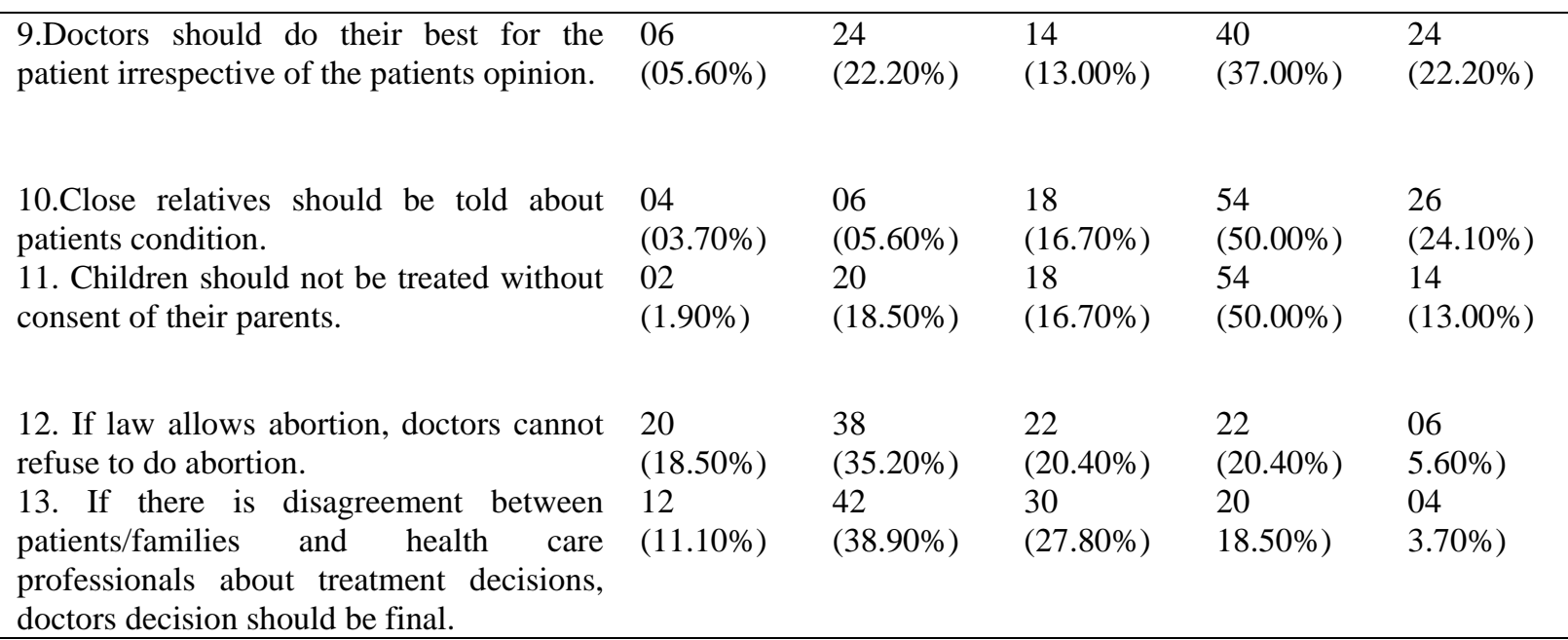

The majority $(n=64,59.30 \%)$ of the specialist medical officers strongly disagree that "confidentiality is not so important aspect of treatment". Out of the 108 respondents $20(18.50 \%)$ strongly disagree and 38(35.02\%) disagree that "if law allows abortion, doctors cannot refuse to do abortion" and $12(11.10 \%)$ strongly disagree and $42(38.90 \%$ ) disagree that "if there is disagreement between patients/families and health care professionals about treatment decisions, doctors decision should be final". (Table 2)

Among the total respondents $26(24.10 \%)$ strongly agree and 54(50.00\%) agree with the statement " close relatives should be told about patients condition", 24(22.20\%) strongly agree and $40(37.00 \%)$ agree with the statement " doctors should do their best for the patient irrespective of the patients opinion" and 16(14.80\%) strongly agree and 54(50.00\%) agree with the statement

"patients should be always informed if health care professionals do something wrong involving their treatment". (Table 2)

Table 3 shows how the respondents practice various dimensions of medical ethics.

According to Table 3 it seems that practices like ". if a patient wishes to die, he or she should be assisted in doing so no matter what their illness", "it is very difficult to keep confidentiality, so it should be abandoned", " ethical conduct is only important to avoid legal actions" and "writing nervous system examination- normal or blood pressure - normal when it hasn't been done, is acceptable because it is important for documentation" are the top 4 practices to which Sri Lankan specialist medical officers are least adhered with frequencies of $(n=32,29.60 \%),(n=30,27.80 \%)$ and $(n=26,24.10 \%)$ respectively.

The majority of the specialist medical officers(n=48,44.40\%) strongly agree and 52(48.10\%) agree that "ethics as a part of syllabus should be taught in every medical teaching institution". This is followed by the practice "copying answers in degree examinations is bad/sin" to which 38 (35.20\%) strongly agree and $46(42.60 \%)$ agree (Table 3$)$. 
Table 3 Respondents practice of medical ethics

\begin{tabular}{|c|c|c|c|c|c|}
\hline Issues in practice of medical ethics & $\begin{array}{l}\text { Strongly } \\
\text { Disagree }\end{array}$ & Disagree & $\begin{array}{l}\text { Neither } \\
\text { Disagree } \\
\text { or Agree }\end{array}$ & Agree & $\begin{array}{l}\text { Strongly } \\
\text { Agree }\end{array}$ \\
\hline $\begin{array}{l}\text { 14.Ethical conduct is only important to avoid } \\
\text { legal actions }\end{array}$ & $\begin{array}{l}26 \\
(24.10 \%)\end{array}$ & $\begin{array}{l}68 \\
(63.00 \%)\end{array}$ & $\begin{array}{l}10 \\
(9.30 \%)\end{array}$ & $\begin{array}{l}02 \\
(01.90 \%)\end{array}$ & $\begin{array}{l}02 \\
01.90 \%)\end{array}$ \\
\hline $\begin{array}{l}\text { 15. Ethics as a part of syllabus should be } \\
\text { taught in every medical teaching institution. }\end{array}$ & $\begin{array}{l}02 \\
(01.90 \%)\end{array}$ & $\begin{array}{l}04 \\
(03.70 \%)\end{array}$ & $\begin{array}{l}02 \\
(01.90 \%)\end{array}$ & $\begin{array}{l}52 \\
48.10 \%)\end{array}$ & $\begin{array}{l}48 \\
(44.40 \%)\end{array}$ \\
\hline $\begin{array}{l}\text { 16. It is very difficult to keep confidentiality, } \\
\text { so it should be abandoned }\end{array}$ & $\begin{array}{l}30 \\
(27.80 \%)\end{array}$ & $\begin{array}{l}46 \\
(42.60 \%)\end{array}$ & $\begin{array}{l}14 \\
(13.00 \%)\end{array}$ & $\begin{array}{l}14 \\
(13.00 \%)\end{array}$ & $\begin{array}{l}04 \\
(3.70 \%)\end{array}$ \\
\hline $\begin{array}{l}\text { 17.I think some doctors are receiving income } \\
\text { from referring patients for medical tests. }\end{array}$ & $\begin{array}{l}24 \\
(22.20 \%)\end{array}$ & $\begin{array}{l}36 \\
(33.30 \%)\end{array}$ & $\begin{array}{l}28 \\
(25.90 \%)\end{array}$ & $\begin{array}{l}16 \\
(14.80 \%)\end{array}$ & $\begin{array}{l}04 \\
(3.70 \%)\end{array}$ \\
\hline $\begin{array}{l}\text { 18. Consent is required only for surgeries, not } \\
\text { for tests and medicines. }\end{array}$ & $\begin{array}{l}20 \\
(18.50 \%)\end{array}$ & $\begin{array}{l}72 \\
(66.70 \%)\end{array}$ & $\begin{array}{l}06 \\
(05.60 \%)\end{array}$ & $\begin{array}{l}08 \\
(07.40 \%)\end{array}$ & $\begin{array}{l}02 \\
(01.90 \%)\end{array}$ \\
\hline $\begin{array}{l}\text { 19.Copying answers in degree examinations } \\
\text { is } \mathrm{bad} / \mathrm{sin} \text {. }\end{array}$ & $\begin{array}{l}02 \\
(01.90 \%)\end{array}$ & $\begin{array}{l}06 \\
(05.60 \%)\end{array}$ & $\begin{array}{l}16 \\
(14.80 \%)\end{array}$ & $\begin{array}{l}46 \\
(42.60 \%)\end{array}$ & $\begin{array}{l}38 \\
(35.20 \%)\end{array}$ \\
\hline $\begin{array}{l}\text { 20. Writing Nervous system examination- } \\
\text { normal or Blood Pressure - normal when it } \\
\text { hasn't been done, is acceptable because it is } \\
\text { important for documentation. }\end{array}$ & $\begin{array}{l}26 \\
(24.10 \%)\end{array}$ & $\begin{array}{l}56 \\
(51.90 \%)\end{array}$ & $\begin{array}{l}10 \\
(09.30 \%)\end{array}$ & $\begin{array}{l}08 \\
(07.40 \%)\end{array}$ & $\begin{array}{l}08 \\
(07.40 \%)\end{array}$ \\
\hline $\begin{array}{l}\text { 21. If a patient wishes to die, he or she should } \\
\text { be assisted in doing so no matter what their } \\
\text { illness. }\end{array}$ & $\begin{array}{l}32 \\
(29.60 \%)\end{array}$ & $\begin{array}{l}56 \\
(51.90 \%)\end{array}$ & $\begin{array}{l}16 \\
(14.80 \%)\end{array}$ & $\begin{array}{l}04 \\
(03.70 \%)\end{array}$ & $\begin{array}{l}00 \\
(00.00 \%)\end{array}$ \\
\hline $\begin{array}{l}\text { 22. I think some doctors are influenced by } \\
\text { drug company inducements, including gifts. }\end{array}$ & $\begin{array}{l}10 \\
(09.30 \%)\end{array}$ & $\begin{array}{l}20 \\
(18.50 \%)\end{array}$ & $\begin{array}{l}20 \\
(18.50 \%)\end{array}$ & $\begin{array}{l}54 \\
(50.00 \%)\end{array}$ & $\begin{array}{l}04 \\
(03.70 \%)\end{array}$ \\
\hline $\begin{array}{l}\text { 23. In order to prevent transmission of } \mathrm{TB} \text {, } \\
\text { disclosure of TB positive status to neighbours } \\
\text { should be done }\end{array}$ & $\begin{array}{l}06 \\
(05.60 \%)\end{array}$ & $\begin{array}{l}28 \\
(25.90 \%)\end{array}$ & $\begin{array}{l}22 \\
(20.40 \%)\end{array}$ & $\begin{array}{l}48 \\
(44.40 \%)\end{array}$ & $\begin{array}{l}04 \\
(03.70 \%)\end{array}$ \\
\hline $\begin{array}{l}\text { 24.If a male doctor needs to examine a female } \\
\text { patient } \& \text { female attendant is not available it } \\
\text { is ethical to refuse the patient. }\end{array}$ & $\begin{array}{l}04 \\
(03.70 \%)\end{array}$ & $\begin{array}{l}24 \\
(22.20 \%)\end{array}$ & $\begin{array}{l}24 \\
(22.20 \%)\end{array}$ & $\begin{array}{l}50 \\
(46.30 \%)\end{array}$ & $\begin{array}{l}06 \\
(05.60 \%)\end{array}$ \\
\hline $\begin{array}{l}\text { 25. I have interest in learning healthcare } \\
\text { ethics. }\end{array}$ & $\begin{array}{l}00 \\
(00.00 \%)\end{array}$ & $\begin{array}{l}06 \\
(05.60 \%)\end{array}$ & $\begin{array}{l}10 \\
(09.30 \%)\end{array}$ & $\begin{array}{l}74 \\
(68.50 \%)\end{array}$ & $\begin{array}{l}18 \\
(16.70 \%)\end{array}$ \\
\hline $\begin{array}{l}\text { 26. I think doctors/nurses must serve hard to } \\
\text { reach areas and underserved population. }\end{array}$ & $\begin{array}{l}00 \\
(00.00 \%)\end{array}$ & $\begin{array}{l}06 \\
(05.60 \%)\end{array}$ & $\begin{array}{l}10 \\
09.30 \%)\end{array}$ & $\begin{array}{l}74 \\
(68.50 \%)\end{array}$ & $\begin{array}{l}18 \\
(16.70 \%)\end{array}$ \\
\hline
\end{tabular}

\section{$4 \longdiv { \text { DISCUSSION } }$}

Among the respondents, majority $(55.60 \%, \mathrm{n}=60)$ were females. This can be explained by the fact that the majority of the Sri Lankan population consists of females(51.60\%)(Department of Census and Statistics, 2012). The mean age of respondents is $42.48(\mathrm{SD}=4.186)$ years and mean experience of $13.63(\mathrm{SD}=3.685$ ) years. The majority belong to the age group of 40-44 years and experience group of $12-16$ years $(50.00 \%, \mathrm{n}=54)$ and $(48.10 \%, \mathrm{n}=52)$ respectively. This may be due to that in Sri Lanka when a doctor passes out from the medical faculty with the bachelors degree he will be around 28 years and by the time he becomes a specialist medical officer he will be around 38 to 40 years. (Table 1)

According to the Sri Lankan study, the majority $(n=64,59.30 \%)$ of the specialist medical officers strongly disagree that "confidentiality is not so important aspect of treatment". (Table 2). This shows that Sri Lankan specialist medical officers respect confidentiality of their patients. This finding is similar to the findings of some other studies done on this topic. In a study done in North India in 2011 among 
298 physicians and 107 nurses, "confidentiality is not so important aspect of treatment" was the top most ethical dimension statement for which the highest number of physicians( $\mathrm{n}=217,81.3 \%)$ strongly disagreed(Chopra et al., 2013). In another study done in Amman, Jordan among medical residents in 2017, "confidentiality is not so important aspect of treatment" was the statement the highest number of respondents(n=95,85.6\%) disagreed(Abdulrazeq, Al-Maamari, Ameen, \& Ameen, 2019).

Out of the 108 respondents 20(18.50\%) strongly disagree and 38(35.20\%) disagree that "if law allows abortion, doctors cannot refuse to do abortion". (Table 2). This may be due cultural and religious beliefs of the specialist doctors, being majority of the population Buddhists(70.10\%)(Department of Census and Statistics, 2012). This is also similar to the study done in Jordan in which $72.10 \%(n=80)$ of the respondents disagree with the same statement(Abdulrazeq et al., 2019). In the North Indian study too, it was found that the same ethical dimension statement came to the top third place with a frequency of 63.90\%(n=156) (Chopra et al., 2013).

According to the Sri Lankan study, 12 participants (11.10\%) strongly disagree and 42 participants $(38.90 \%)$ disagree that "if there is disagreement between patients/families and health care professionals about treatment decisions, doctors decision should be final" (Table 2). This may be due to doctors' fear of lawsuit from patients/ families which has led to decrease their paternalistic attitudes. In the study done in India also, the same statement has become the top second statement to which the majority ( $\mathrm{n}=161,64.40 \%$ ) of the respondents had disagreed with(Chopra et al., 2013).

Among the total respondents $26(24.10 \%)$ strongly agree with the statement "close relatives should be told about patients condition". It should be noted that 54 respondents (50\%) also have agreed with the above statement. (Table 2). This may be also due to that specialist medical officers' fear of allegation from patients' relatives if something goes wrong. In the study done by Chopra and his team, they have found that 242 doctors $(90 \%)$ have agreed with this statement.

Twenty-four respondents (22.20\%) have strongly agreed and 40(37\%) have agreed with the statement "doctors should do their best for the patient irrespective of the patients opinion" (Table 2). This shows that the Sri Lankan specialist doctors are concerned about basic medical principle "beneficence" and also, they have paternalistic attitudes towards their patients. In the study done in Jordan too, the investigators have observed that 67 participants $(60.40 \%)$ have agreed with the above statement( Abdulrazeq, Al-Maamari, Ameen, \& Ameen, 2019).

Out of 108, 16(14.80\%) strongly agree and 54(50.00\%) agree with the statement "patients should be always informed if health care professionals do something wrong involving their treatment" (Table 2). This is similar to the finding in a study done in Nepal in 2016 among 118 resident doctors and 86 nurses in which 83 resident doctors (70.30\%) agreed with the same statement (Adhikari et al., 2016). This is an unusual situation because usually doctors do not accept allegations from public or other 
healthcare professionals about their mistakes. Even though they have personal grudges among them they do not reveal their colleagues' mistakes to the lay people. This finding in the Sri Lankan study is completely different from a study done in Malaysia in 2017 among 348 undergraduate medical students in which $194(56.40 \%$ ) of the respondents had strongly agreed with the statement "He/she should not criticize another physician in the presence of patients or other health personnel" (Jatana et al., 2018). According to this study even though the participants are medical students their attitude about this particular dimension of medical ethics is better than the specialist medical officers.

We found that ". if a patient wishes to die, he or she should be assisted in doing so no matter what their illness" the ethical practice to which 32 respondents $(29.60 \%)$ strongly disagree with and $56(51.90 \%$ ) disagree with: Total $88(81.50 \%$ ) respondents. (Table 3 ). This is no wonder because under Sri Lankan law euthanasia is not legalized. The same situation was observed in a study done

in Pakistan in 2012 among 400 interns, junior and senior post graduate trainees in which $157(90.00 \%)$ of the interns, $105(85.40 \%)$ junior post graduate trainees and $74(89.20 \%)$ senior post graduate trainees claimed that they never practiced(Imran, Haider, Jawaid, \& Mazhar, 2014). In a similar study done in Barbados in 2003 among 364 healthcare professionals 308 (84.60\%) respondents had disagreed with the above-mentioned practice(Hariharan, Jonnalagadda, \& Gora, 2006).

"It is very difficult to keep confidentiality, so it should be abandoned" is an ethical practice to which $30(27.80 \%)$ of the participants strongly disagree with and 46(42.60\%) participants disagree with in the study done in Sri Lanka (Table 3). This finding goes hand in hand with the finding in Table 2 in which the majority $(n=64,59.30 \%)$ of the specialist medical officers strongly disagree that "confidentiality is not so important aspect of treatment". Both these show that Sri Lankan specialist doctors respect the basic ethical principle "confidentiality". In the Indian study too, it was revealed that 222(86.70\%) physicians disagreed with the above statement (Chopra et al., 2013).

We noticed that $26(24.10 \%$ ) respondents strongly disagree and 68(63.00\%) disagree with the practice "ethical conduct is only important to avoid legal actions" in our study (Table 3). It implies that Sri Lankan specialist doctors still do respect ethical code of conducts like Hippocrates Oath on which they swear when they assume duties as junior doctors. In Egypt, in a similar cross-sectional study done in University of Alexandria hospital from 2009 to 2010 by Mohamed and his colleagues among 128 physician residents $122(95.30 \%)$ participants had disagreed with this statement(Mohamed, Ghanem, \& Kassem, 2012). But this is quite different from the observation made in the Indian study in which 132 physicians (52.20\%) had agreed with the practice " ethical conduct is only important to avoid legal actions" (Chopra et al., 2013).

In the Sri Lankan study it was found that out of the 108 respondents, 26(24.10\%) and 56(51.90\%) have strongly disagreed and disagreed respectively with the practice "writing nervous system 
examination- normal or blood pressure - normal when it hasn't been done, is acceptable because it is important for documentation"(Table 3). Patients' Bed Head Tickets (BHTs) are legal documents and it is a common belief that if health care professionals "treat" the BHTs properly they can escape from allegations of medical negligence against them. Despite this belief this is a good trend among Sri Lankan specialist doctors because it implies that not only they "treat" the BHTs, but also they honestly care for the patients. Chopra and his colleagues also have noticed that $157(56.10 \%)$ physicians disagreed with this practice in their study(Chopra et al., 2013).

In our study it was revealed that $48(44.40 \%)$ of the respondents strongly agree and $52(48.10 \%)$ agree with the practice "ethics as a part of syllabus should be taught in every medical teaching institution" (Table 3). Actually, in Sri Lanka in all the medical schools ethics are included in the under graduate curricular. In the Indian study also, it was discovered that 210(85.00\%) of the physicians agree with this practice (Chopra et al., 2013).

"Copying answers in degree examinations is bad/sin" was a practice 38(35.20\%) specialist doctors strongly agree with and 46(42.60\%) agree with (Table 3).In the modern society we come across numerous instances where students are found cheating and copying in competitive national level exams. If Sri Lankan medical specialists do not copy in their highly competitive post graduate exams it will allow the talented, bright doctors to become specialists. Therefore, this is also a very positive practice among Sri Lankan specialist doctors. In the Jordanian study also it was found that $63(56.80 \%)$ of the participants have declared "yes" to this practice( Abdulrazeq, Al-Maamari, Ameen, \& Ameen, 2019). In the North Indian study too, this practice was agreed by $195(68.50 \%)$ of the participants(Chopra et al., 2013).

A major limitation of our study is the small sample size $(\mathrm{N}=120)$. But it is noteworthy that this study was carried out in 04 healthcare institutions which belong to 04 provinces in the country. Therefore, we believe that the generalizability of the results of this study is not a problem. Another limitation is that the practices were studied using a self-administered questionnaire in which the respondents will suffer from social desirability bias. Thirdly, as this was a cross-sectional study, we could not observe the changes over time.

\section{CONCLUSION}

This study shows that Sri Lankan specialist doctors have a sound knowledge and positive attitudes about basic medical ethical principles like autonomy, confidentiality, beneficence and nonmaleficence. They are also very much concerned about lawsuits against them from the patients or their relatives. This also shows that their ethical attitudes towards their own colleagues are below the level of 
their expected standards. Moreover, these findings suggest that their personal cultural and religious beliefs cause dilemmas with their attitudes.

However, their practice is not only aimed at avoiding litigation but also doing good to their patients. They preserve patient autonomy, confidentiality in their practice likewise they have positive attitudes and a good knowledge about these ethical principles. They also seem to be honest in exams as well and willing to learn about medical ethics since their undergraduate period.

\section{RECOMMENDATIONS}

We recommend that education and training in all aspects of medical ethics should be started as continuous medical education for doctors including specialists. Ethics committees should be started in healthcare institutions to support specialist medical officers to take the most appropriate decisions in case of ethical dilemmas. It is further recommended to commence post graduate specialty on medical ethics so that the graduates can be employed as ethicists in hospitals to be members in ethics committees. The specialist doctors should always be encouraged to conduct clinical case conferences to discuss cases of unethical practices and to take preventive measures of such practices in future. But we emphasize that this should be done in a no name, no blame culture. 


\section{REFERENCES}

1. Abdulrazeq, F., Al-Maamari, A., Ameen, W., \& Ameen, A. (2019). Knowledge, Attitudes and Practices of Medical Residents towards Healthcare Ethics in the Islamic Hospital, Jordan. Yemeni Journal of Medical Sciences, 13(1), 1-9. https://doi.org/10.20428/yjms.13.1.a1

2. Adhikari, S., Paudel, K., Aro, A. R., Adhikari, T. B., Adhikari, B., \& Mishra, S. R. (2016). Knowledge, attitude and practice of healthcare ethics among resident doctors and ward nurses from a resource poor setting, Nepal. BMC Medical Ethics, 17(1), 1-8. https://doi.org/10.1186/s12910-0160154-9

3. Baldwin, D., Daugherty, S., \& Rowley, B. (1998). Unethical and unprofessional conduct observed by residents during their first year of training. Acad Med, 73, 1195-1200.

4. Beauchamp, T., \& Childress JF. (2013). Principles of Biomedical Ethics. Oxford University Press.

5. Brogen, S., Rajkumari, B., Laishram, J., \& Joy, A. (2009). knowledge and attitudes of doctors on medical ethics in a teaching hospital, Manipur. Indian Journal of Medical Ethics, 6(4), 194-197.

6. Chopra, M., Bhardwaj, A., Mithra, P., Singh, A., Siddiqui, A., \& DR, R. (2013). Current Status of Knowledge, Attitudes and Practices towards Healthcare Ethics among Doctors and Nurses from Northern India - A Multicentre Study. Journal of Krishna Institute of Medical Sciences University, 2(2), 102-107.

7. Department of Census and Statistics. (2012). Census of Population and Housing 2012.

8. Hariharan, S., Jonnalagadda, R., \& Gora, J. (2006). Knowledge , attitudes and practices of healthcare personnel towards Care-Ethics : A perspective from the Caribbean. The Internet Journal of Law, Healthcare and Ethics, 5(1), 1-8.

9. Imran, N., Haider, I. I., Jawaid, M., \& Mazhar, N. (2014). Health ethics education: Knowledge, attitudes and practice of healthcare ethics among interns and residents in Pakistan. Journal of Postgraduate Medical Institute, 28(4), 383-389.

10. Iswarya, S., \& Bhuvaneshwari, S. (2018). Knowledge and attitude related to medical ethics among medical students. International Journal of Community Medicine and Public Health, 5(6), 22222225 .

11. Jalal, S., Imran, M., Mashood, A., Younis, M., \& Peshawer, C. M. H. (2018). Awareness about Knowledge, Attitude and Practice of Medical Ethics pertaining to Patient Care, among Male and Female Physicians Working in a Public Sector Hospital of. European Journal of Environment and Public Health, 2(1), 1-8.

12. Janakiram, C., \& Gardens, S. J. (2014). Knowledge, attitudes and practices related to healthcare ethics among medical and dental postgraduate students in south India. Indian Journal of Medical Ethics, XI(2), 99-104.

13. Jatana, S. K., Htoo, H., Soe, K., Phyu, K. L., Lwin, H., \& Than, N. N. (2018). A Survey on Knowledge and Attitudes towards Medical Ethics among Undergraduate Medical Students. Education, 
8(3), 48-53. https://doi.org/10.5923/j.edu.20180803.03

14. Mohamed, A. M., Ghanem, M. A., \& Kassem, A. A. (2012). Knowledge, perceptions and practices towards medical ethics among physician residents of University of Alexandria hospitals, Egypt. Eastern Mediterranean Health Journal, 18(9), 935-945. https://doi.org/10.26719/2012.18.9.935 